\title{
De aansluiting tussen het hoger onderwijs en de arbeidsmarkt: een theoretisch kader
}

Citation for published version (APA):

Borghans, L., de Grip, A., \& Heijke, J. A. M. (1989). De aansluiting tussen het hoger onderwijs en de arbeidsmarkt: een theoretisch kader. Researchcentrum voor Onderwijs en Arbeidsmarkt, Faculteit der Economische Wetenschappen. ROA Reports No. 6 https://doi.org/10.26481/umarep.1989006

Document status and date:

Published: 01/01/1989

DOI:

10.26481/umarep.1989006

Document Version:

Publisher's PDF, also known as Version of record

\section{Please check the document version of this publication:}

- A submitted manuscript is the version of the article upon submission and before peer-review. There can be important differences between the submitted version and the official published version of record.

People interested in the research are advised to contact the author for the final version of the publication, or visit the DOI to the publisher's website.

- The final author version and the galley proof are versions of the publication after peer review.

- The final published version features the final layout of the paper including the volume, issue and page numbers.

Link to publication

\footnotetext{
General rights rights.

- You may freely distribute the URL identifying the publication in the public portal. please follow below link for the End User Agreement:

www.umlib.nl/taverne-license

Take down policy

If you believe that this document breaches copyright please contact us at:

repository@maastrichtuniversity.nl

providing details and we will investigate your claim.
}

Copyright and moral rights for the publications made accessible in the public portal are retained by the authors and/or other copyright owners and it is a condition of accessing publications that users recognise and abide by the legal requirements associated with these

- Users may download and print one copy of any publication from the public portal for the purpose of private study or research.

- You may not further distribute the material or use it for any profit-making activity or commercial gain

If the publication is distributed under the terms of Article $25 \mathrm{fa}$ of the Dutch Copyright Act, indicated by the "Taverne" license above, 
DE AANSLUITING TUSSEN HET HOGER ONDERWIJS EN DE ARBEIDSMARKT:

EEN THEORETISCH KADER

ROA-R-1989/6

Lex Borghans

Andries de Grip

Hans Heijke

RESEARCHCENTRUM VOOR ONDERWIJS EN ARBEIDSMARKT

Faculteit der Economische Wetenschappen

Rijksuniversiteit Limburg

Maastricht, december 1989 
CIP-GEGEVENS KONINKLIJKE BIBLIOTHEEK, DEN HAAG

Borghans, Lex

De aansluiting tussen het hoger onderwijs en de arbeidsmarkt: een theoretisch kader / Lex Borghans, Andries de Grip, Hans Heijke. - Maastricht : Researchcentrum voor Onderwijs en Arbeidsmarkt, Faculteit der Economische Wetenschappen, Rijksuniversiteit Limburg. - (Rapport / Researchcentrum voor Onderwijs en Arbeidsmarkt, ISSN 0922-8098; 1989/6)

Met 1it. opg.

ISBN 90-5321-027-X

SISO 318.7 UDC $373.5: 331.5$

Trefw. onderwijs en arbeidsmarkt. 
INHOUDSOPGAVE

Bladzijde

VERANTWOORDING

1. INLEIDING 1

2. ASPECTEN VAN DE AANSLUITINGSPROBLEMATIEK 3

2.1. De aard van de problematiek 3

2.2. Oorzaken van de aansluitingsproblematiek 6

2.2.1. Vijf groepen van oorzaken 6

2.2.2. Aanbodsrestricties 7

2.2.3. De rol van onderwijsinstellingen 10

2.2.4. Onvolledige informatie aan de aanbodkant 12

2.2.5. Invloed van andere motieven op het aanbod 14

2.2.6. Loonvoet en produktiviteit 15

2.2.7. Onvolledige informatie aan de vraagkant 17

2.3. Interactie tussen verschillende verstorende werkingen 19

2.4. Ruimtelijke aspecten van de aansluitingsproblematiek 20

2.5. Instrumenten voor verandering 21

2.6. Evaluatie van beleid 26

3. VOORWAARDEN VOOR HET ONDERZOEK 28

3.1. Het belang van informatie 28

3.2. Behoefte aan data 28

3.3. Adequate classificaties 31

4. SAMENVATTING EN CONCLUSIES 33

4.1. Samenvatting: De relatie tussen onderzoek, 33 gegevensverzameling en beleid

4.2. Conclusies 35

$\begin{array}{ll}\text { LITERATUUR } & 37\end{array}$ 


\section{VERANTWOORDING}

Dit rapport is geschreven in opdracht van de Commissie Beleidsonderzoek Hoger Onderwijs en Wetenschappelijk Onderzoek (CBHW). Deze commissie heeft ondermeer tot taak te adviseren bij de totstandkoming van het meerjarig programma beleidsonderzoek DGHW van het Ministerie van Onderwijs en Wetenschappen. Om zich nader te oriënteren op ontwikkelingen en mogelijkheden op het gebied van de theorievorming en het onderzoek betreffende de aansluiting hoger onderwijs-arbeidsmarkt, verzocht de commissie het ROA, vanuit zijn specifieke deskundigheid en ervaring, een analyse te maken van perspectiefvolle ontwikkelingen in de theorievorming en het empirisch onderzoek op het gebied van de aansluiting hoger onderwijs-arbeidsmarkt.

Gezien de beperkte omvang van deze opdracht, moesten wij ons in dit rapport beperken tot een aanduiding van de aspecten die vanuit onze visie relevant zijn voor deze onderzoeksvraag en konden we geen volledig literatuuronderzoek op dit terrein verrichten. De nadruk in dit rapport ligt dan ook vooral op de aspecten, waarvan binnen het ROA reeds expertise aanwezig was. 
1. INLEIDING

De relatie tussen onderwijs en arbeid is de laatste jaren opnieuw in de belangstelling gekomen. Niet alleen binnen het wetenschappelijk onderzoek, in disciplines zoals sociologie en economie, maar ook bij velen die betrokken zijn bij het beleid op onderwijsgebied is de aandacht zich gaan richten op de rol die het onderwijs speelt bij het functioneren van de arbeidsmarkt.

In dit rapport worden perspectiefvolle ontwikkelingen beschreven in de theorievorming en het empirisch onderzoek met betrekking tot de aansluiting tussen het hoger onderwijs en de arbeidsmarkt. Dit gebeurt op verzoek van de Commissie Beleidsonderzoek Hoger Onderwijs en Wetenschappelijk Onderzoek (CBHW), die zich hiermee wil oriënteren op de mogelijkheden voor het ontwikkelen van een onderzoekslijn op het gebied van de aansluitingsproblematiek onderwijs-arbeidsmarkt. De commissie wil zich hierbij met name richten op onderzoek dat kan bijdragen aan vergroting van fundamentele kennis in de zin van theoretische inzichten en resultaten van empirische toetsing.

Om te komen tot een adequate opzet voor een onderzoekslijn met betrekking tot de aansluitingsproblematiek, zijn vele aspecten van belang. Het zoeken naar theoretisch inzicht kan niet los worden gezien van vragen over de aard van de problematiek en de mogelijkheden tot verbetering van de situatie. Het gaat hier immers om beleidsonderzoek. Hierbij hebben theoretische kennis en empirische informatie directe implicaties voor het te voeren beleid. Verder kan theoretisch onderzoek alleen vruchtbaar zijn indien aan een aantal randvoorwaarden is voldaan. Deze randvoorwaarden worden bepaald door de mogelijkheid om adequate informatie te verkrijgen over het te bestuderen onderwerp. De kwaliteit van onderzoek dat beoogt gefundeerd te zijn op empirie wordt immers begrensd door de kwaliteit van die empirische informatie.

Ten slotte is het van groot belang om ook bij onderzoek dat slechts op bepaalde facetten van de aansluitingsproblematiek is gericht, steeds oog te blijven houden voor de context warin dit onderzoek zich afspeelt. Alleen op deze wijze kan worden voorkomen dat er versnippering optreedt, als gevolg van ad hoc geformuleerde onderzoeksvraagstellingen. De voortgang van de grote lijn wordt uiteraard het beste gewaarborgd indien specifieke probleemstellingen voor onderzoek voortkomen uit een algemeen perspectief en indien de resultaten van specifieke onderzoeken telkens weer geplaatst worden binnen dit onderzoekskader. 
In dit rapport is daarom gekozen voor een brede opzet, waarbij steeds economische theorieën en denkwijzen als uitgangspunt dienen. In hoofdstuk 2 wordt ingegaan op de verschillende aspecten van de aansluitingsproblematiek. In paragraaf 2.1. wordt kort ingegaan op de aard van de problematiek. In paragraaf 2.2. wordt de localisering en werking van de factoren die de aansluitingsproblematiek bepalen' besproken. Daarna wordt gekeken hoe deze oorzaken op elkaar in kunnen werken (2.3.). Vervolgens komen de ruimtelijke aspecten van de aansluitingsproblematiek aan bod (2.4.). In paragraaf 2.5 . wordt aangegeven hoe verkregen inzichten in de aansluitingsproblematiek kunnen worden gebruikt bij het verbeteren van de situatie. Tenslotte wordt ingegaan op de noodzaak van en de mogelijkheden voor een evaluatie van het gevoerde beleid (paragraaf 2.6.).

In hoofdstuk 3 wordt aandacht besteed aan de voorwaarden voor het onderzoek. In het licht van de bevindingen uit hoofdstuk 2 wordt allereerst aangegeven welke data nodig zijn voor kwalitatief fundamenteel onderzoek (paragraaf 3.2.). In paragraaf 3.3. wordt bekeken in hoeverre het specifieke probleemgebied van de aansluiting onderwijs-arbeidsmarkt vraagt om voor haar doelstellingen beter geschikte classificaties, om zo de data beter geschikt te maken voor het te bestuderen probleem.

In hoofdstuk 4 worden de belangrijkste verbanden samengevat en worden enkele conclusies getrokken. Met behulp van een schema wordt het verband tussen fundamenteel onderzoek, informatievoorziening en beleid in beeld gebracht.

Tot slot van deze inleiding willen wij er nog op wijzen dat het niet het doel van dit rapport is een volledig literatuuroverzicht te geven op het gebied van de aansluiting tussen het hoger onderwijs en de arbeidsmarkt. De literatuurverwijzingen zijn slechts bedoeld als voorbeeld. Evenmin worden in dit rapport concrete onderzoeksvoorstellen voor de CBHW gedaan. Wij menen dat dit een taak van de commissie blijft. Uiteraard hebben wij gestreefd om in dit rapport voldoende ingrediënten te verwerken, op basis waarvan de commissie tot onderzoeksvoorstellen kan komen. 


\section{ASPECTEN VAN DE AANSLUITINGSPROBLEMATIEK}

\subsection{De aard van de problematiek}

Om tot een goed inzicht te komen in de mogelijkheden van de instrumenten van het onderwijsbeleid, dient niet alleen onderzocht te worden hoe de relatie onderwijs-arbeidsmarkt functioneert. Een voorwaarde voor een zinvolle benadering van de aansluitingsproblematiek is allereerst een adequaat inzicht in de aard van de problematiek. Het gaat hier immers om onderzoek dat als basis voor beleid kan dienen en daartoe dient duidelijk te zijn waarop dat beleid zich wil richten. Dat dit geen triviale vraagstelling is wordt in deze paragraaf uiteen gezet.

Het achtervoegsel 'problematiek' in het woord 'aansluitingsproblematiek' impliceert in feite al een bepalde visie op de aansluiting tussen onderwijs en arbeidsmarkt. Er wordt voorondersteld dat er sprake is van een niet optimale, of zelfs verre van optimale situatie, warin hopelijk verbetering kan worden aangebracht. Er wordt uitgegaan van het feit dat er discrepanties bestaan tussen vraag en aanbod op de arbeidsmarkt, waarbij wordt verondersteld dat deze discrepanties niet noodzakelijk zijn. Zij kunnen dus door een verbetering van de situatie worden opgeheven.

Van Hoof en Dronkers (1980) onderscheiden kwantitatieve en kwalitatieve aansluitingsproblemen: "De term kwantitatieve aansluitingsproblematiek slaat op discrepanties bij de allocatie van kwalificaties; het gaat dan om discrepanties op de arbeidsmarkt, tussen aangeboden en gevraagde kwalificaties; de term kwalitatieve aansluitingsproblematiek slaat op discrepanties bij de benutting van kwalificaties; het gaat dan om discrepanties binnen de werksituatie tussen beschikbare en vereiste kwalificaties"1.

Het is echter niet zonder meer duidelijk wat onder een discrepantie verstaan moet worden. Een belangrijke benaderingswijze voor scholingsdiscrepanties is de 'manpower requirements'-benadering2. Hierin worden aan de ene kant het te verwachten aanbod van studenten, uitgesplitst naar kwalificaties, en aan de andere kant de te verwachten vraag van werkgevers naar bepaalde kwalificaties in kaart gebracht. Vervolgens worden deze twee naast elkaar

1. Van Hoof en Dronkers (1980), blz. 32.

2. Zie bijvoorbeeld Psacharopoulos (1987). 
gelegd en wordt gekeken waar de verschillen liggen, oftewel waar zich discrepanties bevinden. Deze invalshoek is vooral van betekenis voor het signaleren van bepaalde discrepanties, maar kan niet zonder meer gebruikt worden voor een theoretische benadering, waarin gepoogd wordt een verklaring van de werking van de aansluiting tussen vraag en aanbod te geven. In een economische visie staan immers altijd kosten tegenover baten. Er is niet sprake van een bestaande vraag naar arbeid zonder meer, maar van een vraag naar bepaalde kwalificaties gegeven bepaalde kosten. Vraag en aanbod kunnen niet als autonoom worden beschouwd, maar moeten worden gezien in hun onderlinge samenhang. Vraag naar arbeid is geen exogene grootheid, maar de resultante van een afweging van de werkgever tussen enerzijds de voordelen die het aantrekken van bepaalde arbeidskracht hem kan opleveren (de baten) en anderzijds de mogelijkheden die het aanbod hem biedt (de kosten). Als gevolg hiervan ontstaat substitutie, bijvoorbeeld tussen arbeid en kapitaal of tussen verschillende soorten arbeid onderling. Gegeven de verschillende produktiemogelijkheden wordt gezocht naar optimale combinaties van produktiefactoren. Hoger gekwalificeerd personeel zal vaak duurder zijn of is misschien helemaal niet te vinden. Voor een ondernemer kan dat aanleiding zijn om goedkoper personeel met lagere kwalificaties als substituut aan te nemen. Vraag moet in een theoretische context dus steeds begrepen worden als de vraag gegeven de mogelijkheden aan de aanbodkant, terwijl aanbod moet worden gezien als aanbod gegeven de mogelijkheden aan de vraagkant. Vraag en aanbod staan derhalve in een voortdurende wisselwerking met elkaar.

Men kan pas spreken van een slechte aansluiting tussen vraag en aanbod, indien er wordt uitgegaan van een bepalde doelstelling of een bepaald begrip van optimaliteit. Er zijn immers meerdere partijen betrokken bij het hoger onderwijs en de arbeidsmarkt, die elk hun eigen belangen kunnen hebben. Verder kan een situatie vanuit een individu gezien optimaal zijn, maar vanuit een macro-gezichtspunt toch onwenselijk zijn.

Op het terrein van het hoger onderwijs en de arbeidsmarkt zijn met name de studenten en de werknemers, de werkgevers, de onderwijsinstellingen (hogescholen en universiteiten) en de overheid belanghebbenden. Voor een ondernemer betekent een goede aansluiting vooral dat studenten of werknemers de kwaliteiten hebben die hij nodig acht voor de produktie in vergelijking met de kosten die hier tegenover staan. Voor de aanbieder van arbeid betekent een goede aansluiting vooral een aantrekkelijke baan zonder belemmeringen in de loopbaan. De aantrekkelijkheid kan zowel tot uiting komen in een hoog 
loon, alsook in interessant werk of goede arbeidsomstandigheden. De overheid zal daarentegen vooral hechten aan macro-economische doelstellingen en een rechtvaardige verdeling van inkomen en kennis over de bevolking. Er kan dus zowel sprake zijn van meer micro- alsook van meer macro-geörienteerde doelstellingen.

Het is duidelijk dat de keuze van het optimaliteitsbegrip bepaalt wat wel en wat niet een discrepantie is. Indien iedereen het werk doet dat hij leuk vindt, is volgens de doelstelling van werknemers geen sprake van een discrepantie. Als men een maximale produktie wenst te bereiken en hiervoor een andere verdeling van arbeid nodig is, kan er wel degelijk sprake zijn van een discrepantie. De produktie zou immers vergroot kunnen worden als arbeiders hun leuke baan zouden inruilen voor een meer produktieve baan.

Bij het signaleren van discrepanties spelen naast de (impliciete) doelstellingen ook de theoretische uitgangspunten een belangrijke rol. Als vanuit een bepaalde theorie een discrepantie wordt geconstateerd kan dit op twee dingen wijzen. Ten eerste kan er werkelijk zo een discrepantie bestaan, maar ten tweede kan het ook zo zijn dat er meer factoren een rol spelen dan de gehanteerde theorie vooronderstelt. Als men er van uit gaat dat het menselijke handelen wordt gedreven door het zoeken naar optimaliteit, dan ligt het voor de hand om bij een geconstateerde discrepantie, dat wil zeggen bij een op het eerste gezicht niet optimale situatie, de vraag te stellen of er misschien toch een reden is waarom de situatie is zoals hij is. Dat bepaalde discrepanties bij nadere beschouwing toch een doelmatigheid kunnen hebben wil nog niet zeggen dat ze ook gewenst zijn. Deze doelmatigheid hoeft immers niet overeen te stemmen met de doelstellingen van waaruit de aansluitingsproblematiek bekeken wordt.

Enkele voorbeelden uit de economische theorie kunnen hierop licht werpen. Het bekendste voorbeeld is de arbeidsverdeling. Arbeidsverdeling leidt aan de ene kant tot vergroting van de produktiviteit, doordat individuele capaciteiten beter gebruikt kunnen worden, waardoor comparatieve voordelen benut worden, en personen zich op een bepaalde specialisatie kunnen toeleggen, wat schaalvoordelen met zich mee kan brengen. Aan de andere kant is de arbeidsverdeling ook de grote oorzaak van aansluitingsproblemen. Indien specialisatie niet nodig was, zouden er immers ook geen aansluitingsproblemen zijn. Iedereen zou een algemene scholing krijgen en de inhoud van dat scholingsprogramma zou alleen moeten worden afgestemd op de algemene 
behoeftes van studenten en werkgevers. Vanuit de optimaliteitsgedachte zou nu beredeneerd kunnen worden dat kennelijk de mate van specialisatie zodanig is dat de marginale opbrengst van de specialisering gelijk is aan de marginale kosten van de door deze specialisering veroorzaakte aansluitingsproblemen. Studenten zijn in dat geval niet bereid zich verder te specialiseren omdat de opbrengst hiervan, bijvoorbeeld in de vorm van extra loon, niet opweegt tegen de grotere risico's op aansluitingsproblemen in de vorm van een verminderde kans op het vinden van een geschikte baan. Ook aan werkgeverskant heeft specialisatie van de arbeid voordelen, bijvoorbeeld door een verhoging van de produktiviteit, maar kan ook voor hen een kostenpost zijn doordat het steeds moeilijker zal worden iemand van het juiste specialisme te vinden. Om te achterhalen of hier werkelijk sprake is van een discrepantie moeten de kosten en de baten van specialisatie in de theorie worden ingebracht.

Dit voorbeeld laat zien, ook als niet zonder meer wordt uitgegaan van een optimale situatie, dat voor beleidsmatregelen niet de opheffing van de bestaande aansluitingsproblemen zonder meer centraal moet staan, maar dat de aansluiting verbeterd moet worden zonder dat dit onevenredig ten koste van andere aspecten gaat.

Naast dit arbeidsverdelingsprobleem zijn er nog andere voorbeelden waarbij ook een belangenafweging plaats dient te vinden. Zo kan er worden gekeken naar beroepsbescherming, diploma-eisen en loonstarheid. Alle drie kunnen zij de aansluitingsproblemen vergroten, maar daar staat tegenover dat ze op een ander terrein juist een economisch voordeel kunnen bewerkstelligen. Beroepsbescherming leidt tot een grotere werkzekerheid, diploma-eisen kunnen bijdragen aan een kwaliteitsgarantie in de richting van de consument en loonstarheid kan zorgen voor risico-afwenteling van werknemer naar werkgever of kan ongewenste concurrentie tussen werknemers voorkomen.

\subsection{Oorzaken van de aansluitingsproblematiek}

\subsubsection{Vijuf groepen van oorzakeken}

Het eenvoudige economische beeld van een ideaal werkende arbeidsmarkt is het bekende plaatje van een met een stijgend loon dalende vraagcurve en een stijgend loon stijgende aanbodscurve. Het evenwicht, dat bepaald wordt door het snijpunt van beide curven, garandeert een volledige aansluiting van het 
aanbod van arbeid op de behoeftes van werkgevers (gedacht vanuit het klassieke Pareto-optimaliteitsidee). Alle arbeid wordt daar ingezet waar het gebruik het meest optimal is en iedereen werkt onder een optimale verhouding tussen werk en andere tijdsbestedingen.

Het is bekend dat de arbeidsmarkt in de praktijk zo niet functioneert. ' $\mathrm{Er}$ is meer tussen vraag en aanbod dan menig econoom tot voor kort bevroedde' 3 . De werkelijkheid blijkt heel wat complexer in elkaar te steken dan het eenvoudige evenwichtsplaatje doet vermoeden. Verstoringen van dit ideaalbeeld manifesteren zich vaak als aansluitingsproblemen. Daarom kan aan de hand van dit beeld een overzicht worden gemaakt van de mogelijke oorzaken van aansluitingsproblemen.

In deze paragraaf worden de aansluitingsproblemen in vijf groepen ingedeeld4. Een eerste indeling kan plaatsvinden naar verstoringen aan de aanbodkant en verstoringen aan de vraagkant van de arbeidsmarkt. Aan de aanbodkant kan dan weer onderscheid worden gemaakt tussen verstoringen die zijn veroorzaakt door restricties op de onderwijskeuze (2.2.2. en 2.2.3.), verstoringen die zijn ontstaan door onvolledige informatie (2.2.4.) en verstoringen die zijn ontstaan doordat er in de onderwijskeuze ook motieven een rol spelen die niet in het kader onderwijs-arbeidsmarkt passen (2.2.5.). ook aan de vraagzijde kunnen restricties aan het gedrag zijn gesteld die voortvloeien uit andere facetten dan de aansluiting van vraag en aanbod op de arbeidsmarkt. Zo kunnen bijvoorbeeld vakbondsinvloeden beperkingen opleggen aan de loonflexibilitieit (2.2.6.). Verder kunnen ook aan de vraagkant informatieproblemen een rol spelen $(2.2 .7$.$) .$

\subsubsection{Aanbodsrestricties}

Allereerst de restricties op de onderwijskeuze. We spreken van restricties als het om factoren gaat die binnen de economische beschouwingswijze als gegeven worden aangereikt. Hierbij kan worden gedacht aan een aantal soorten beperkingen. Ten eerste zijn er beperkingen die worden opgelegd door het sociale milieu, waaruit studenten afkomstig zijn. Ouders die vinden dat hun dochter niet hoeft te studeren, of integendeel juist per se hun kind op de

3. Hartog (1980), b1z. 1 .

4. In De Grip (1987) wordt een zeer uitgebreid overzicht gegeven van de mogelijke oorzaken van scholingsdiscrepanties. 
universiteit willen zien. Verder is al vaak het verband aangetoond tussen het sociale milieu en de onderwijskeuze. Wat betreft de aansluiting tussen onderwijs en arbeidsmarkt wordt op dit gebied in Nederland de meeste aandacht besteed aan het traditionele kiesgedrag van meisjes. Een voorbeeld hiervan is het boek Meer of minder ongelijk van Diederen (1989). Van Mourik, De Poel en Siegers (1983) schetsen de ontwikkelingen in de beroepssegregatie naar geslacht. Een actie zoals kies exact weerspiegelt het belang dat in het overheidsbeleid aan het opheffen van deze aanbodsrestricties wordt gehecht. Deze op emancipatie gerichte beleidsmaatregel gaat kennelijk uit van de doelstelling om optimale ontwikkelingsmogelijkheden voor iedereen te creëren.

Een tweede soort restricties wordt gevormd door feitelijke regulering van de opleidingskeuze. Hierbij kan worden gedacht aan de diploma-eisen bij de toelating tot het hoger onderwijs en de beperkingen zoals een numerus fixus. Hoewel dit soort maatregelen juist vaak regulerend bedoeld zijn, kunnen ze ook verstorend werken op het arbeidsmarktevenwicht.

Onderzoek op dit terrein is gedaan door 0.a. Albinski, in Studentenstop. Verslag van een simulatieproject (1976). In deze studie ligt echter vooral de nadruk op de gevolgen die een studentenstop heeft voor de toestroom in andere studierichtingen en wordt niet gekeken naar de verstoring van het marktmechanisme dat door de stop wordt veroorzaakt. Twee punten lijken hierbij van belang. Ten eerste kan er een verstorende werking uitgaan op de selectie van studenten. Sommige goede studenten zullen niet kunnen studeren doordat ze zijn uitgeloot, terwijl andere makkelijker hun weg vinden doordat de concurrentie minder is geworden. Dit kan leiden tot een niet optimale allocatie van arbeidsproduktiviteit als sommige studenten die relatief produktief zouden zijn in het desbetreffende vakgebied reeds bij voorbaat worden uitgesloten. Door de keuze van de selectiemethode kan dit probleem verkleind worden. In Nederland gebeurt dit door bij de loting studenten met hogere eindexamencijfers een groter gewicht te geven. Deze benadering veronderstelt dat de eindexamencijfers informatief zijn over de capaciteiten voor de studie.

Als een studentenstop gebruikt wordt als maatregel ter voorkoming van arbeidsmarktdiscrepanties is een tweede probleem, dat er bij het instrument studentenstop door de overheid een keuze moet worden gemaakt. Het is de vraag of de overheid zo een keuze beter kan maken dan de markt. Centraal 
hierbij staat de vraag of de overheid nieuwe tendenzen op de arbeidsmarkt beter kan aanvoelen dan de individuele studenten. Zarkin (1985) laat zien dat studenten wel degelijk in staat zijn op arbeidsmarktontwikkelingen te anticiperen.

Een derde vorm van restrictie op de onderwijskeuze is de financiering van het onderwijs. Twee aspecten die hierbij in de literatuur naar voren komen zijn het studiefinancieringsstelsel en de kapitalmarkt. In de theoretische literatuur wordt vaak verondersteld dat er een perfect werkende kapitaalmarkt is. Dat wil zeggen dat als een student meent dat het zinvol is om in een opleiding te investeren alvorens te gaan werken hij dit altijd via de kapitaalmarkt kan financieren. Dit is doorgaans niet het geval. De verstorende werking die deze imperfectie van de kapitaalmarkt heeft op de onderwijskeuze is bestudeerd door Kodde in Microeconomic Analysis of Demand for Education (1985). Hierin komt ook de rol van de studiefinanciering aan de orde. Dit is in feite de tegenpool van de slecht werkende kapitaalmarkt. Om de studenten die geen geld kunnen lenen toch te laten studeren financiert de overheid de kosten van hun onderwijsinvestering. Met name de empirische resultaten van dit onderzoek zijn nog niet erg duidelijk, hetgeen grotendeels veroorzaakt wordt door gebrek aan geschikte data. In Nederland heeft immers bijna iedereen dezelfde mogelijkheden voor het verkrijgen van studiefinanciering, terwijl juist variatie hierin zou kunnen leiden tot empirische duidelijkheid. Als alternatief kan gedacht worden aan een internationaal vergelijkend onderzoek.

Ook de (leer)capaciteiten van studenten vormen een restrictie op het aanbod. Al is de vraag naar een bepaalde soort hooggekwalificeerde arbeid nog zo groot, als slechts weinig studenten de capaciteit hebben zich deze arbeid eigen te maken, zal het aanbod beperkt zijn. Zo zou men zich kunnen afvragen of dergelijke barrières bestaan bij de technische wetenschappen en andere beta-studierichtingen. Tinbergen (1975) bespreekt de rol van capaciteiten in het aanbod van arbeid. De keuze voor een bepaalde opleiding wordt volgens hem mede bepaald door aspecten die over de beschouwde tijdspanne constant zijn voor één individu, maar die variëren tussen individuen. Hierbij kan een onderscheid gemaakt worden tussen 'produktie-capaciteiten' en 'consumptiebehoeften'. Voorbeelden van 'produktie-capaciteiten' zijn cognitieve capaciteiten, maar ook de capaciteit om beslissingen te nemen, de capaciteit om zelfstandig te werken en de bereidheid tot samenwerken 5 .

5. Tinbergen (1975), blz, 58-59. 


\subsubsection{De_rol van onderwijs}

Een van de belangrijkste restricties binnen het kader van de aansluiting van het onderwijs op de arbeidsmarkt is het scala aan studierichtingen dat door de onderwijsinstellingen wordt aangeboden. Het is immers niet zo dat er voor ieder denkbare opleiding een studierichting bestaat. Aan de andere kant hoeft het feit dat de beschikbare studierichtingen een belangrijke restrictie vormen, nog niet te betekenen dat het hier ook om een zware belemmering gaat. In het gunstigste geval worden net die opleidingen waaraan ook behoefte is aangeboden.

Er zijn ook voordelen verbonden aan de beperking van het aantal studierichtingen. Een belangrijk argument voor slechts een beperkt aantal opleidingen zijn de directe kosten die aan het onderwijs verbonden zijn. In de kostenstructuur van het onderwijs spelen schaalvoordelen een belangrijke rol en die zouden wegvallen als het aantal studierichtingen sterk zou toenemen. Aan de andere kant blijft het echter mogelijk om binnen een instituut toch een groot aantal afstudeermogelijkheden open te houden, zoals dat op universiteiten gebruikelijk is. Hier kan meestal iedere student individueel zijn specialisatie ontwikkelen. Het feit dat dit op hogescholen vaak minder het geval is kan duiden op een verschillende functie van beide typen onderwijs.

Naast de schaalvoordelen zijn er echter nog andere argumenten voor een beperking van het aantal opleidingen. Een gering aantal afstudeerrichtingen betekent immers meer overzichtelijkheid. Een student kan voor hij aan een studie begint waarschijnlijk toch geen duidelijke keuze maken voor een bepaald specialisme. Door eerst een globalere richting te kiezen, die later weer mogelijkheden laat voor verdere specialisatie, wordt het keuzeproces beter ondersteund.

Voor de werkgever kan het ook van belang zijn dat er duidelijkheid bestaat over de bestaande opleidingen. Bij een beperkt aantal erkende diploma's kan hij het bezit van zulke diploma's op zijn waarde schatten. Bij een te groot aantal diploma's weet hij niet meer wat de betekenis is van een bepaald diploma. De kans is dan groot dat een werkgever bij zijn wervingsbeleid zich zal beperken tot de studierichtingen waarmee hij in het verleden goede ervaringen heeft opgedaan. 
In de literatuur, zowel de economische als de niet economische, wordt veel aandacht geschonken aan de inhoud die opleidingen zouden moeten hebben om zo goed mogelijk aan te sluiten bij de behoeften van de arbeidsmarkt. Weinig aandacht wordt echter besteed aan de wijze waarop en de snelheid waarmee onderwijsinstellingen zich aanpassen aan de veranderende behoeften aan de vraag- en aanbodkant van de arbeidsmarkt. Vanuit de aansluitingsproblematiek gezien zou het wellicht gewenst zijn als een onderwijsinstelling de doelstelling zou hebben om deze aansluiting zo goed mogelijk te bevorderen. Er spelen echter vele andere belangen een rol in het gedrag van de onderwijsinstantie. Door de manier waarop een universiteit of hogeschool wordt gefinancierd zal de doelstelling vaak eerder gericht zijn op vergroting van het aantal studenten dan op het verbeteren van de aansluiting tussen vraag en aanbod op de arbeidsmarkt. Deze doelstellingen hoeven niet onderling strijdig te zijn, maar kunnen dit wel zijn. Bij een afnemende vraag naar arbeid met een bepaalde type opleiding zal een onderwijsinstelling de neiging hebben het studieprogramma te verleggen in een richting met een grotere behoefte, om zo de werkgelegenheid van de instelling veilig te stellen. Instellingen verdringen zich dan voor de grote studentenaantallen. Aan de vraagkant van de arbeidsmarkt kan er echter wel degelijk nog behoefte zijn aan het oude studieprogramma, maar dan met een kleiner aantal studenten.

Een tweede factor kan zijn dat onderwijsinstellingen die een grotere vrijheid krijgen hun eigen programma vast te stellen, gaan inspelen op modetendensen bij de studenten. De beslissingen die studenten nemen op grond van onvolledige informatie worden hiermee versterkt. De laatste tijd zijn op universiteiten vele nieuwe studierichtingen opgericht. Men zou hier de kritische vraag kunnen stellen of deze richtingen een werkelijke innovatie op onderwijsgebied zijn of dat ze zijn ontstaan om strategische belangen van de instellingen te dienen.

Op het gebied van de onderwijsinnovatie speelt ook de keuze tussen algemene en vakspecialistische opleidingen een rol. Is het van belang dat universiteiten en hogescholen specialisten opleiden, waarvan verwacht kan worden dat ze op hun gebied onmiddellijk ingezet kunnen worden of zijn functies altijd zo specifiek dat werkgevers hun nieuwe werknemers toch altijd moeten 'trainen' voor de nieuwe baan, en werknemers dus beter een algemene achtergrond kunnen hebben? Thurow (1979) wijst op het belang van 'trainability' voor werknemers. De voor een baan relevante kennis en vaardigheden worden 
pas bij de vervulling van die baan aangeleerd. Onderwijs heeft alleen als functie mensen opleidbaar te maken, zodat ze snel en met weinig kosten voor de werkgever, voluit kunnen functioneren in hun nieuwe baan.

Samenhangend met deze trainability is verder de relatie tussen initieel onderwijs en onderwijs op latere leeftijd. Als de vereiste kennis en vaardigheden voor een baan te specifiek zijn om vooraf te leren, kan het zinvol zijn een deel van het onderwijs van de initiële onderwijsperiode door te schuiven naar de toekomst in de vorm van vakcursussen of volwasseneneducatie. Als men reeds enige tijd op een bepaalde plaats werkzaam is, weet men beter aan welke kennis- en vaardigheidsontwikkeling men behoefte heeft. De sector of het bedrijf waarin men een loopbaan wil ontwikkelen is dan bekend en men heeft ervaren waar de eigen tekortkomingen liggen. Door een dergelijke feed-back-onderwijsbenadering kunnen aansluitproblemen wellicht verkleind worden.

Ook kan onderwijs op latere leeftijd 'versleten' kennis weer opfrissen. Kennis en vaardigheden depreciëren doordat mensen vergeetachtig zijn, de techniek verandert en ook doordat men soms enige tijd uit het arbeidsproces kan raken. Dit laatste speelt veelal bij vrouwen, maar ook bij mensen die langdurige ziek zijn geweest. Volwassenenonderwijs kan deze achteruitgang van kennis en vaardigheden tegengaan en zo kan een achterstand weer weggewerkt worden.

\subsubsection{Onvolledige informatie_aan de aanbodkant}

In het eenvoudige model van vraag en aanbod wordt impliciet verondersteld dat zowel de vragers als de aanbieders van arbeid beschikken over volledige informatie over de markt. Hierdoor zijn zij in staat voor een optimale allocatie te zorgen. Deze vooronderstelling van volledige informatie is echter zeker op de arbeidsmarkt veel te sterk. Een aantal specifieke kenmerken van het onderwijs en de arbeidsmarkt bemoeilijken het verkrijgen van de juiste informatie over de markt.

Ten eerste is de arbeidsmarkt geen overzichtelijk geheel. Er bestaat een enorm aantal beroepen met daarbinnen nog vele specialisaties en er kan gewerkt worden bij talloze grote en kleine bedrijven die allemaal hun eigen functie-eisen stellen. Het goed arbeid is verre van homogeen. Eerder zou men kunnen stellen dat geen enkele functie gelijk is aan een andere. Dit makt 
het praktisch onmogelijk om een volledig beeld van de arbeidsmarkt te krijgen. Van belang is daarom de vraag in hoeverre de informatievoorziening invloed heeft op de keuzes die studenten maken en in hoeverre de onduidelijkheid van de arbeidsmarkt leidt tot keuzeproblemen. Er zou kunnen worden nagegaan of het zinvol is om orde in de complexiteit te scheppen door of het maken van inzichtelijke indelingen (segmentatie) of door het vereenvoudigen van de arbeidsmarkt zelf door het stimuleren van de definiëring en afbakening van duidelijke opleidingen en daarbij aansluitende beroepsgroepen, respectievelijk via certificering en instroom-eisen en via diploma-eisen en registratie. Bij een vereenvoudiging van de arbeidsmarkt zelf moet altijd in de overweging worden meegenomen dat dit tevens kan leiden tot een verstarring van de aansluiting. De voordelen zullen dus moeten worden afgewogen tegen de nadelen.

Een tweede aspect van het informatieprobleem betreft de informatie over de behoeften van werkgevers aan bepaalde soorten opleidingen en de beloning die daaraan is verbonden. In de 'human capital'-theorie wordt verondersteld dat de beslissing om te investeren in menselijk kapitaal, dat wil zeggen de beslissing om een bepalde opleiding te volgen, zodanig wordt genomen dat het life-time inkomen of het life-time nut wordt gemaximaliseerd. Om een afgewogen investeringsbeslissing te kunnen maken, dient een student dan precies te weten welke inkomensstroom hij kan verwachten na het volgen van een bepaalde opleiding.

Het is echter praktisch onmogelijk een compleet overzicht van dit soort gegevens te hebben. Daarvoor is de structuur van de arbeidsmarkt veel te complex. Beloningen hangen niet alleen af van de gevolgde opleidingen, maar hangen ook samen met andere individuele kenmerken en zijn daarnaast afhankelijk van de functie die men verkrijgt. Dit is in tegenstelling tot wat de human capital theorie veronderste $t^{6}$. Verder blijkt niet alleen het loon, maar ook een aantal andere aspecten van de functie een rol te spelen in de opleidingskeuze. De human-capital-theorie veronderstelt bovendien ten onrechte dat de arbeidsmarkt volledig door de lonen wordt geruimd. Aangezien dit niet het geval is, spelen ook andere factoren die de allocatie op de arbeidsmarkt bepalen, zoals de kans op werk, een rol in de opleidingskeuze7. 6. Zie bijvoorbeeld J. Hartog (1986), Earnings functions: beyond human
capital.

7. Zie Thurow (1975). 
Naast de complexiteit van de beloningsstructuur wordt in de literatuur ook veel aandacht geschonken aan het feit dat er een vertraging zit tussen de investeringsbeslissing om onderwijs te volgen en het moment dat men met de verworven kennis en vaardigheden op de arbeidsmarkt komt. In de jaren dat men studeert kan er veel veranderen op de arbeidsmarkt. Studenten zouden, om een goede keuze te kunnen maken, in staat moeten zijn deze veranderingen volledig te voorzien. Dit is doorgaans niet het geval, zodat er discrepanties kunnen ontstaan tussen de opleiding die feitelijk gekozen is en de opleiding die gekozen zou zijn als men op de hoogte was geweest van de veranderingen die zich hebben voorgedaan op de arbeidsmarkt.

De meest in het oog springende variant van dit informatieprobleem wordt beschreven met het varkenscyclusmode18. Verondersteld wordt dat studenten hun studiekeuze maken op grond van de huidige arbeidsmarktsituatie, in plaats van de situatie op het moment dat zij de arbeidsmarkt betreden. Als nu de lonen in een bepalde richting relatief hoog zijn, dan zullen veel studenten kiezen voor die richting. Na afronding van de studie, bijvoorbeeld vier jaar later, zullen er te veel studenten op de arbeidsmarkt komen met die studierichting. Afhankelijk van de hoogte van de loonelasticiteit van de vraag en de uitwijkmogelijkheden van deze studenten zal nu het loon dalen, waardoor minder studenten zullen kiezen voor de desbetreffende richting. Over vier jaar zal dat dan weer een daling van de uitstroom betekenen, waardoor het loon weer zal stijgen.

\subsubsection{Invloed van andere motieven op het aanbod}

Een laatste factor die in de literatuur te vinden is als oorzaak van scholingsdiscrepanties is de invloed op de onderwijskeuze van motieven, die los staan van de relatie onderwijs-arbeidsmarkt. Het voorbeeld hiervan is het volgen van onderwijs om consumptieve redenen. Omdat studenten niet alleen studeren om daar een betere positie op de arbeidsmarkt mee te krijgen, maar ook omdat ze studeren leuk vinden of omdat ze studeren van belang achten voor hun persoonijjke ontwikkeling, bestaat er een neiging om meer onderwijs te volgen dan op grond van pure arbeidsmarktmotieven verklaard kan worden. Dit kan een van de oorzaken zijn van het fenomeen 'overscholing'9. ook kan dit consumptiemotief gevolgen hebben voor de richting die gekozen

8. Bijvoorbeeld door Freeman (1976).

9. Zie Freeman (1980). 
wordt. Het is echter de vraag of consumptiemotieven als oorzaak van overscholing ook mag worden gezien als een oorzaak van scholingsdiscrepanties. De student heeft immers, volgens de theorie, in alle vrijheid en bewust van de gevolgen gekozen voor een opleiding die hoger is dan waar de functie die hij zal krijgen om vraagt. Aan de andere kant moet worden betwijfeld of een dergelijke keuze voor onderwijs als consumptiegoed door studenten zo duidelijk wordt onderscheiden van onderwijs als investeringsgoed. Dit is echter een efficiency-argument op micro-niveau, vanuit het gezichtspunt van de student. Op macro-niveau kan dit weer anders liggen. De overheid kan van oordeel zijn dat zij het onderwijs niet wil financieren om daarmee consumptiemogelijkheden te scheppen. Zij zal eerder als doel hebben het intellectuele kapitaal van het land te vergroten en zal daarom een verschuiving naar consumptiemotieven ongewenst vinden. Hier speelt weer het in paragraaf 2.1. besproken punt, dat bepaalde verschijnselen pas een aansluitingsprobleem zijn als ze gezien worden vanuit een bepaalde doelstelling.

\subsubsection{Loonvoet_en_produktiviteit}

In het eenvoudige neo-klassieke model is de loonvoet van een bepaalde soort arbeid gelijk aan de marginale produktiviteit van deze arbeid. Deze gelijkheid zorgt er voor dat het loon een goed signaal is naar de aanbodkant voor de behoefte aan arbeid aan de vraagkant. Er zijn echter talloze theorieën die laten zien dat de gelijkheid tussen loonvoet en produktiviteit niet hoeft op te gaan. Voor de vraagkant van de arbeidsmarkt betekent dit een restrictie op de mogelijkheden om met de lonen het aanbod van arbeid te sturen.

Allereerst is er het belastingstelsel dat een verstoring teweeg brengt van de relatie tussen de arbeidsproduktiviteit en de netto loonvoet. Omdat de belasting echter niet afhangt van het soort werk, maar alleen van het loon, heeft deze factor vooral invloed op het totale aanbod van arbeid en minder op de verdeling van het aanbod over de verschillende richtingen. De invloed kan echter wel verschillend zijn tussen hoog en laag betaalde banen. Bij een progressief belastingstelsel zal de vermindering van hoog betaalde arbeid groter zijn dan die van laag betaalde arbeid. Van Soest, Woittiez en Kapteyn (1989) laten echter zien dat dit effect veel kleiner is dan men zou verwachten, doordat er slechts een beperkte flexibiliteit is in het aantal gewerkte uren. Een hogere belasting kan daarom niet onmiddellijk worden omgezet in 
een verkleining van het aantal gewerkte uren. Wel wijzen de auteurs er op dat het bestaan van deze uren-restrictie een discrepantie tussen vraag en aanbod veroorzaakt, doordat er een groot aanbodpotentieel is dat alleen in deeltijd wil werken, maar dat door een tekort aan deeltijdbanen van betaalde arbeid afziet.

Een tweede verklaring voor de ongelijkheid tussen loon en produktiviteit wordt geleverd vanuit de institutionele hoek. Benadrukt wordt dat de hoogte van de lonen worden bepaald door afspraken en regelingen en niet door de wet van vraag en aanbod 10 . Hierdoor ontstaat loonstarheid die in somige deelmarkten een aanbodoverschot en in andere deelmarkten een aanbodtekort teweeg brengt. Dit punt speelt ook een belangrijke rol in de post-Keynesiaanse literatuur 11 .

In theorieën van meer recente datum wordt geprobeerd een vorm van rationaliteit achter loonstarheid te vinden. De naam die hierbij vooral genoemd moet worden is Stiglitz ${ }^{12}$. De centrale gedachte van zijn theorieën is dat loon niet alleen een instrument is voor het in evenwicht brengen van de markt, maar dat de hoogte van het loon ook invloed heeft op de produktiviteit, de betrouwbaarheid van de werknemers en de mobiliteit. De ondernemer kan dus niet zonder meer het loon gebruiken als instrument voor het beïnvloeden van het arbeidsaanbod, maar wordt in zijn handelen beperkt door nevenvoorwaarden die hem door bovengenoemde relaties worden opgelegd. Als er een licht overschot op de arbeidsmarkt is en de ondernemer zou daarom het loon een beetje verlagen, zouden bijvoorbeeld werknemers gedemotiveerd kunnen raken en een slechte arbeidsprestatie gaan leveren en misschien hard op zoek gaan naar een andere baan. De loonhoogte in dat geval wordt bepaalt door het 'efficiency wage'.

Een belangrijke theorie over de verschillen tussen loon en produktiviteit is de impliciete-contract-theorie. Hierin wordt verondersteld dat de relatie tussen werkgever en werknemer beschouwd moet worden alsof er een contract tussen beiden bestaat, warin voor alle gevallen die zich zouden kunnen voordoen is geregeld wat er zal gebeuren met de te leveren werkprestatie en

10. Zie bijvoorbeeld Van Voorden (1975).

11. Zie bijvoorbeeld Malinvaud (1977).

12. Bijvoorbeeld Theories of Wage Rigidity (1986). 
het 10on. Een gevolg van een dergelijke 'afspraak' kan zijn dat de werkgever een constant loon over de tijd aanbiedt ongeacht de produktiviteit op een bepaald moment, om zo het risico van bijvoorbeeld conjunctuurschomelingen over te hevelen van werknemer naar werkgever. Een werkgever zal doorgaans minder risicomijdend zijn dan de werknemer en kan in ruil voor het overgenomen risico een lager loon uitbetalen. Een ander voorbeeld is een loonstructuur waarbij de werknemer aanvankelijk minder krijgt uitbetaald dan zijn produktiviteit, maar later meer krijgt uitbetaald dan zijn produktiviteit. Dit betekent voor de werknemer een stimulans om niet van baan te veranderen (hij heeft immers steeds nog een 'tegoed' bij zijn werkgever dat hij verliest als hij vertrekt). Voor de werkgever kan een laag verloop van geschoold personeel waardevol zijn en dit voordeel kan gedeeld worden tussen werkgever en werknemer, zodat het impliciete contract voor beide waardevol is 13 .

Hoewel het feit dat de lonen geen weergave van de produktiviteit zijn, invloed lijkt te hebben op de aansluiting tussen het onderwijs en de arbeidsmarkt is deze invloed nooit systematisch onderzocht. Wel is gekeken naar de consequenties die loonstarheid en impliciete contracten hebben voor de werkgelegenheid in zijn geheel.

\subsubsection{Onvolledige informatie_aan_de vraagkant}

Hoewel in de literatuur bij scholingsdiscrepanties vooral wordt gewezen op onvolledige informatie aan de kant van de studenten, bestaat er ook aan de kant van de werkgevers geen volledige informatie. Dit vraagstuk is vooral uitgewerkt voor de problemen die de ondernemer heeft bij het vaststellen van de kwaliteiten van werknemers. Omdat de werkgever nooit exact kan bepalen wat de eigenschappen (kwaliteiten) van een bepaalde werknemer zijn, maakt hij gebruik van indicatoren (kwalificaties). Een indicatie voor kwaliteit is bijvoorbeeld het bezit van een bepald diploma. Iemand die in staat is om een bepaald diploma te behalen dient op zijn minst de eigenschappen te bezitten die nodig zijn voor het succesvol beëindigen van de desbetreffende opleiding. Dit is de zogenaamde signalling- of screeningtheorie14. Het bezit van een diploma geeft dus een indicatie van de te verwachten produktiviteit.

13. Voor een overzicht over implicit contracts zie S. Rosen (1985) of D.0. Parsons (1986).

14. Zie Spence (1973). 
Aan de andere kant geeft ook het niet bezitten van een diploma informatie, want als een student de vereiste capaciteiten had, zou hij wel het diploma hebben gehaald. Het informatie-belang van diploma's kan er toe leiden dat studenten alleen vanwege dit screeningselement, meer opleiding volgen dan voor hun produktiviteit optimaal is. Dit blijkt bijvoorbeeld uit het feit dat bijna iedere student stopt met studeren op het moment dat een bepaald diploma is behaald. Kennelijk wordt het diploma als waardevoller beschouwd dan de kennis die is opgedaan bij de studie.

Volgens Thurow (1975) is een werkgever vaak meer geïnteresseerd in de 'trainability' van een werknemer dan in zijn reeds aanwezige kennis. Het diploma geeft een goede indicatie van het feit dat een student in staat zal zijn ook de kennis en de vaardigheden op te doen, die nodig zijn voor het adequaat uitoefenen van een bepaalde functie. De kennis die de student reeds heeft wordt niet zo belangrijk gevonden. Op het werk zal de werknemer via extra opleiding de benodigde kennis alsnog kunnen vergaren.

Ook andere tekenen uit het verleden kunnen een indicatie vormen, zoals het feit dat iemand al enige tijd bij een bepaald bedrijf heeft gewerkt. Ook kan een werkgever besluiten via doorstroming in het eigen bedrijf mensen te selecteren op hun kwaliteit en zo komen tot een interne arbeidsmarkt 15.

Een tweede informatieprobleem aan de werkgeverskant dat bij het voorgaande aansluit betreft de kennis of de eigenschappen die nodig zijn voor een bepaalde functie. Bij een bestaande functie zal een ondernemer veelal niet precies weten welke vooropleiding het beste aansluit en op welk niveau een persoon geworven dient te worden. Dit zal er veelal toe leiden dat de reputatie van een opleiding, al dan niet terecht, een grote rol zal spelen bij het aannamebeleid van ondernemers. Bovendien zal een werkgever de neiging hebben, zo lang als de arbeidsmarkt dit toelaat, steeds hogere opleidingseisen te stellen. Dit leidt tot een wachtrij van aanbieders van arbeid. Degene met de hoogste opleiding of de meeste ervaring komt het eerste aan bod. Mensen met minder opleiding en ervaring dienen te wachten totdat zij aan de beurt zijn. De werkgever is niet in staat een duidelijke inschatting van de te verwachten produktiviteit te maken. Hij kan dus ook niet de afweging maken om iemand verderop in de rij aan te nemen tegen een lager 10on. Er ontstaat job-competition in de plaats van wage-competition 16 .

15. Zie Doeringer en Piore (1971).

16. Thurow (1979). 
Sterker nog, volgens de theorie van Stiglitz zal een 'mindere' werknemer door zich tegen een lager loon aan te bieden alleen het signaal af geven 'minder' te zijn en daarom zijn kansen verkleinen. Een werkgever zal immers redeneren dat iemand die bereid is voor weinig geld te komen werken kennelijk ook geen hoge produktiviteit heeft.

Een derde manier om indicatoren te gebruiken bij het selecteren van personeel is de discriminatie. Omdat een ondernemer niet goed in staat is om persoonlijke kenmerken van arbeidskrachten waar te nemen, laat hij zijn beslissing afhangen van hun groepskenmerken. Bij individuele kenmerken moet niet alleen gedacht worden aan opleiding e.d., maar vooral ook aan betrouwbaarheid, kans op ziekte, samenwerkingsproblemen met het al aanwezig personeel enz. De werkgever kan deze eigenschappen niet per individu afzonderlijk bepalen en daarom veronderstelt hij dat een afzonderlijk individu de gemiddelde kenmerken heeft van de groep waartoe hij of zij behoort. Dit gedrag is een verklaring voor het bekende probleem van discriminatie van vrouwen en etnische minderheden. Een gevolg van dit discriminerende selectiegedrag is dat individuen met capaciteiten die boven het gemiddelde liggen van de groep waartoe zij gerekend worden, deze capaciteiten niet zullen kunnen benutten, omdat de werkgever er steeds van uit gaat dat zij deze niet zullen bezitten. Het heeft voor een individu dan ook geen zin om deze eigenschappen verder te ontwikkelen. Hierin komt pas verandering als òf de hele groep deze capaciteiten verder ontwikkelt ò als er voor individuen een mogelijkheid komt deze eigenschap aan te tonen.

\subsection{Interactie tussen verschillende verstorende werkingen}

In de vorige paragraaf zijn een aantal mogelijke oorzaken van scholingsdiscrepanties aan bod gekomen. Deze oorzaken kunnen echter niet zonder meer los van elkaar gezien worden. Aan de hand van een aantal voorbeelden kan de mogelijke wisselwerking tussen verschillende oorzaken van aansluitingsproblemen geillustreerd worden.

In de subparagraaf 'onvolledige informatie aan de aanbodkant' werd ingegaan op het feit dat gebrek aan informatie er toe kan leiden dat studenten niet juist reageren op een veranderende situatie aan de vraagkant. Zij signaleren bijvoorbeeld niet dat er sprake is van stijgende lonen in een bepaalde beroepsgroep. Dit tekort aan informatie kan leiden tot aansluitingsproblemen. Een impliciete veronderstelling hierbij is echter dat de lonen een 
goede indicatie vormen van de behoeftes aan de vraagkant. Maar in de subparagraaf 'loonvoet en produktiviteit' werd juist getoond hoe allerlei interne factoren er toe kunnen leiden dat binnen een bedrijf de loonvoet niet meer gelijk is aan de marginale produktiviteit.

Het zou zo kunnen zijn dat als studenten wel adequaat reageren op deze onjuiste signalen er juist aansluitingsproblemen ontstaan. In dit licht bezien zou het kunnen zijn dat juist een onvolledige reactie op de lonen discrepanties voorkomt.

Een tweede voorbeeld van wisselwerking tussen twee oorzaken van scholingsdiscrepanties betreft overscholing en de wachtrijtheorie. Volgens de eerste theorie bestaat er een tendens onder studenten om meer opleiding te volgen dan vanuit een investeringsperspectief noodzakelijk is. Hierbij wordt echter weer verondersteld dat de produktiviteit van een werknemer het loon bepaalt. Volgens de wachtrijtheorie komen echter alleen de studenten met de hoogste opleiding en de meeste ervaring aan bod, zodat het volgen van een zo hoog mogelijke opleiding voor het desbetreffende individu wel degelijk zin heeft. op macro-niveau betekent dit echter wel een inefficiëntie.

Een derde voorbeeld van een interactie tussen twee mogelijke oorzaken van discrepanties is de relatie tussen de belastingen en de rigiditeit van het aantal gewerkte uren. Doordat een individu niet precies zijn optimale aantal uren kan werken, maar genoegen moet nemen met een door de werkgever aangeboden baan, kan een belastingverhoging niet worden afgewenteld op het aantal gewerkte uren. Hoewel en de belastingen en de urenrigiditeit oorzaken kunnen zijn van discrepanties, zou het opheffen van een van de twee niet automatisch een verbetering van de situatie betekenen. Door bijvoorbeeld de urenrigiditeit op te heffen zouden de ongewenste gevolgen van het belastingsysteem wel eens meer kunnen toenemen dan de flexibilisering van het aantal gewerkte uren op zou leveren.

\subsection{Ruimtelijke aspecten van de aansluitingsproblematiek}

Een bijzondere plaats binnen de aansluitingsproblematiek wordt ingenomen door de ruimtelijke aspecten. Hierbij kan zowel gekeken worden naar regionale als ook naar internationale aspecten. De relaties op het terrein van de aansluitingsproblematiek, zoals die geschetst werden in de voorgaande subparagrafen gelden ook hier, maar het ruimtelijke aspect levert enkele 
nieuwe gezichtspunten op.

De restricties van het aanbod van arbeid kunnen ruimtelijk bepaald zijn. Zo zal het aanbod van arbeid tussen landen veel beperkter zijn dan binnen een land. Er zal echter niet alleen tussen landen, maar ook tussen regio's een beperkte mobiliteit zijn. De drempel om je streek of land te verlaten en ergens anders onderwijs te volgen of werk te zoeken kan hoog zijn. Hierbij spelen zowel de geografische afstand, de culturele verschillen (vooral de taal is een belangrijke barrière), alsook restricties door feitelijke regulering een rol.

Op internationaal niveau moet er rekening mee worden gehouden dat diploma's niet altijd wederzijds worden erkend en studenten uit andere landen niet zonder meer worden toegelaten tot de onderwijsprogramma's. Een interessante vraag is in hoeverre de mobiliteit tussen landen zou toenemen als deze institutionele beperkingen zouden worden opgeheven. Als, bijvoorbeeld binnen de $E_{. G}$., het opheffen van deze belemmeringen zou leiden tot een vergroting van de mobiliteit, is het van belang te weten welk soort arbeidskrachten naar een ander land zullen vertrekken en in welke richting deze mobiliteit plaats zal vinden. In sommige landen zou er een ongewenste 'brain-drain' plaats kunnen vinden.

De informatie over de mogelijkheden en de kansen op de arbeidsmarkt, die binnen één land al vaak verre van afdoende is, zal internationaal ook een grote belemmering zijn voor het goed op elkaar aansluiten van vraag en aanbod. Andersom geldt ook dat werkgevers niet goed weten wat de betekenis is van een bepaald buitenlands diploma. Verder is de inhoud van het onderwijs in veel studierichtingen toegespitst op de binnenlandse situatie.

Een grondig onderzoek op dit gebied, samen met een 'monitoring' van vraag en aanbod in de verschillende landen, met name in aangrenzende regio's, zou de aansluitingsproblemen kunnen verkleinen. De mogelijkheid dat in het ene land juist een tekort is aan een specialisme waaraan elders een overschot is, is niet ondenkbaar.

\subsection{Instrumenten voor verandering}

De doelstellingen van beleidsgericht onderzoek gaan uiteraard verder dan een pure inzichtverwerving in de oorzaken van de aansluitingsproblematiek. Dit 
inzicht moet kunnen worden gebruikt als ondersteuning voor het nemen van maatregelen die de situatie verbeteren. Er moet dan ook worden nagegaan welke mogelijke beleidsinstrumenten voor handen zijn en welke invloed deze hebben op de in de vorige paragraaf behandelde werking van de aansluiting van het onderwijs op de arbeidsmarkt. Vervolgens moet bekeken worden of de effecten van zo een ingrijpen bijdragen tot een verbetering van de situatie aan de hand van inzichten over de aard van de problematiek uit de eerste paragraaf van dit hoofdstuk. De relatie tussen maatregel en gevolg moet nooit als mechanisch worden gezien. De werking van de aansluiting tussen onderwijs en arbeidsmarkt wordt immers hoofdzakelijk bepaald door een complex van gedragsrelaties.

Schema I en II geven een beeld van de wijze waarop de relatie tussen het hoger onderwijs en de arbeidsmarkt functioneert, aansluitende bij de oorzaken van de aansluitingsproblematiek zoals die in paragraaf 2.2 . geschetst werden. De schema's hebben slechts een heuristisch karakter. De mogelijke oorzaken zoals die in paragraaf 2.2. aan bod kwamen zijn immers nog niet volledig onderzocht. De schema's moeten dan ook gezien worden als een voorlopige kijk op de werking van de relatie tussen het onderwijs en de arbeidsmarkt. Nieuwe gegevens over de aansluitingsproblematiek kunnen aanleiding zijn voor nieuw onderzoek en kunnen leiden tot nieuwe inzichten. De schema's zouden dan aangepast moeten worden.

Schema I (zie blz. 23) geeft een statisch beeld van de aansluitingsproblematiek. Een aantal aspecten die aan de orde kwamen in paragraaf 2.2 . komen hierin terug. Studenten kiezen voor een bepaalde opleiding. Maar deze keuze wordt beperkt door restricties zoals het sociale milieu, de wetgeving, de financieringsmogelijkheden en de individuele capaciteiten. Verder zijn ze bij de keuze niet alleen gericht op de arbeidsmarkt, maar kunnen ook andere motieven een rol spelen. Tenslotte speelt de informatievoorziening een belangrijke rol. Zonder goede informatie over hun mogelijkheden en de consequenties van de te maken keuzen, kan geen verantwoorde besluitvorming plaatsvinden. Aan de andere kant staan de werkgevers die arbeid moeten selecteren. Ook zij beschikken niet over perfecte informatie en worden daarnaast nog beperkt in hun mogelijkheden, doordat zij hun beleid niet alleen op de arbeidsmarkt kunnen richten, maar ook rekening moeten houden met andere facetten van hun bedrijf. Daarnaast speelt nog de rol van de overheid die van bovenaf allerlei invloeden kan uitoefenen, en de wijze waarop onderwijsinstellingen inspelen op vraag en aanbod op de arbeidsmarkt. 

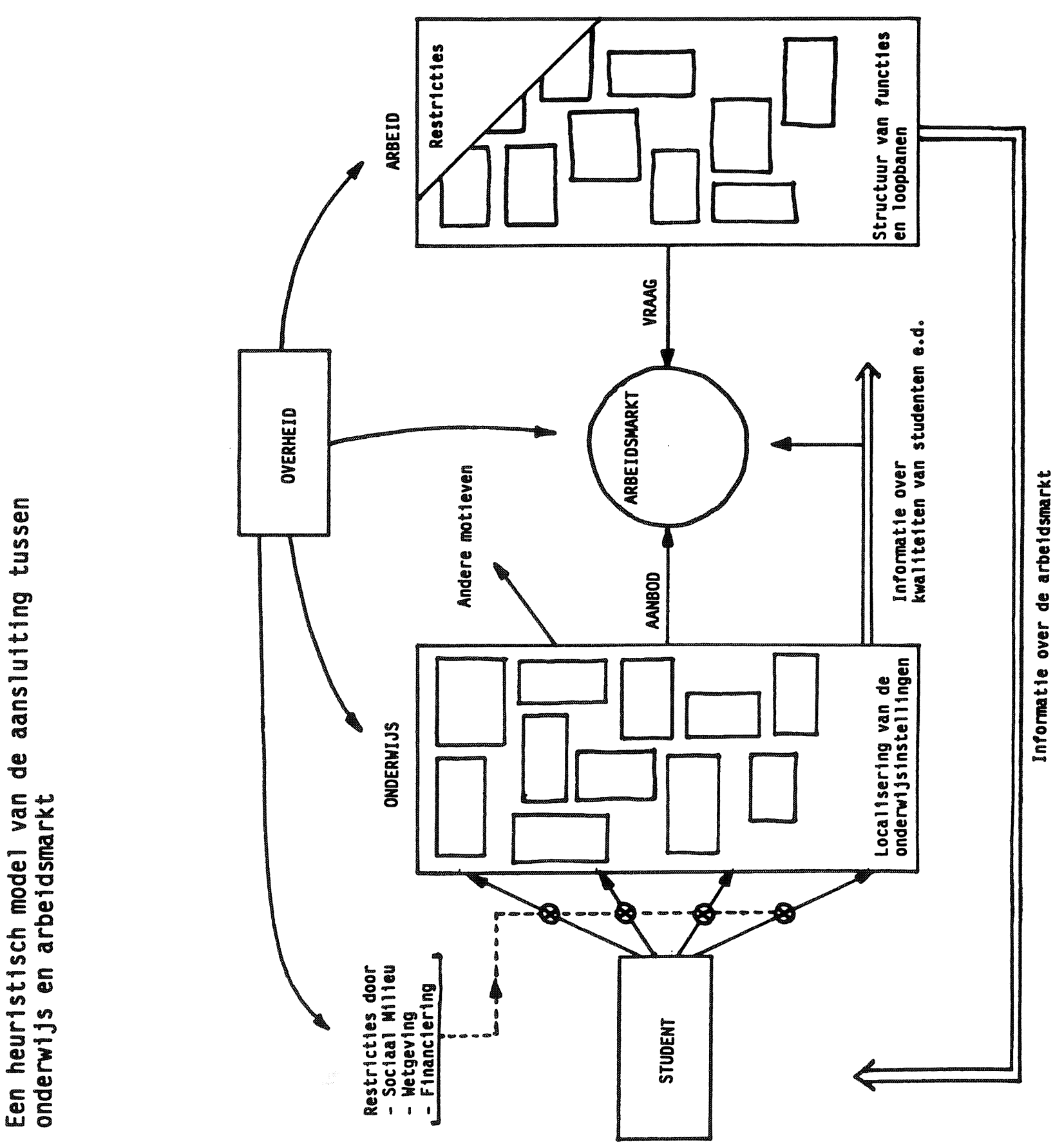

包 
Schema II (zie blz. 25) toont de relatie tussen het onderwijs en de arbeidsmarkt vanuit een dynamisch perspectief. Sectorverschuivingen en technologische ontwikkeling bepalen de vraag naar arbeid; opleidingskeuzen en demografische ontwikkeling bepalen het aanbod van arbeid. Een confrontatie van vraag en aanbod kan leiden tot aansluitingsproblemen. Deze aansluitingsproblemen zijn echter geen voldongen feit. Een confrontatie met aansluitingsproblemen zal werkgevers en werknemers er toe bewegen de eisen of de kwalificaties aan te passen. Aan de kant van de werknemer zal dit leiden tot nieuwe scholing of tot mobiliteit. Aan de kant van de werkgever zal dit leiden tot aanpassing van de functie-eisen of vergroting van de aantrekkelijkheid van een baan door bijvoorbeeld het loon te verhogen of de werkzaamheden interessanter te maken.

Vraag en aanbod op de arbeidsmarkt zijn dus geen gegeven grootheden, maar worden continu aangepast. Deze aanpassing wordt gestimuleerd door de geconstateerde aansluitingsproblemen. Dit wil echter niet zeggen dat door deze dynamiek alle aansluitingsproblemen zullen verdwijnen. Vaak zal het moment waarop het probleem geconstateerd wordt te laat zijn voor een optimale aanpassing aan de omstandigheden. Beleid op dit gebied zal dus nodig blijven.

Een aantal mogelijke beleidsinstrumenten is impliciet al in de vorige paragraaf aan bod gekomen. Zo heeft de overheid de mogelijkheid van studentenstops, studiefinanciering, stimuleringsbeleid enz. Onderzocht moet worden in hoeverre deze instrumenten de aansluitingsproblemen kunnen verminderen. Ook kan omgekeerd te werk worden gegaan. Uitgaande van een bepaalde oorzaak van aansluitingsproblemen kan een beleidsinstrument ontwikkeld worden. Op basis van het inzicht dat de theorie geeft over dit probleem kan gekeken worden welk beleid het meest geschikt is om dit probleem aan te pakken.

Beleidsinstrumenten kunnen onderverdeeld worden in curatieve en preventieve instrumenten. Met een curatief instrument kunnen na het ontstaan van een aansluitingsprobleem maatregelen genomen worden die de situatie verhelpen of de pijn verzachten. Bij de eerste groep kan gedacht worden aan om-, her-, of bijscholing van werklozen; bij de tweede groep aan tewerkstellingssubsidies voor langdurig werklozen.

Een preventief beleid is gericht op het voorkomen van aansluitingsproblemen. Uiteraard verdient preventief beleid de voorkeur boven curatief beleid. Toch 
Schema II Een heuristisch model van de dynamische aspecten van de aansluiting tussen onderwijs en arbeidsmarkt

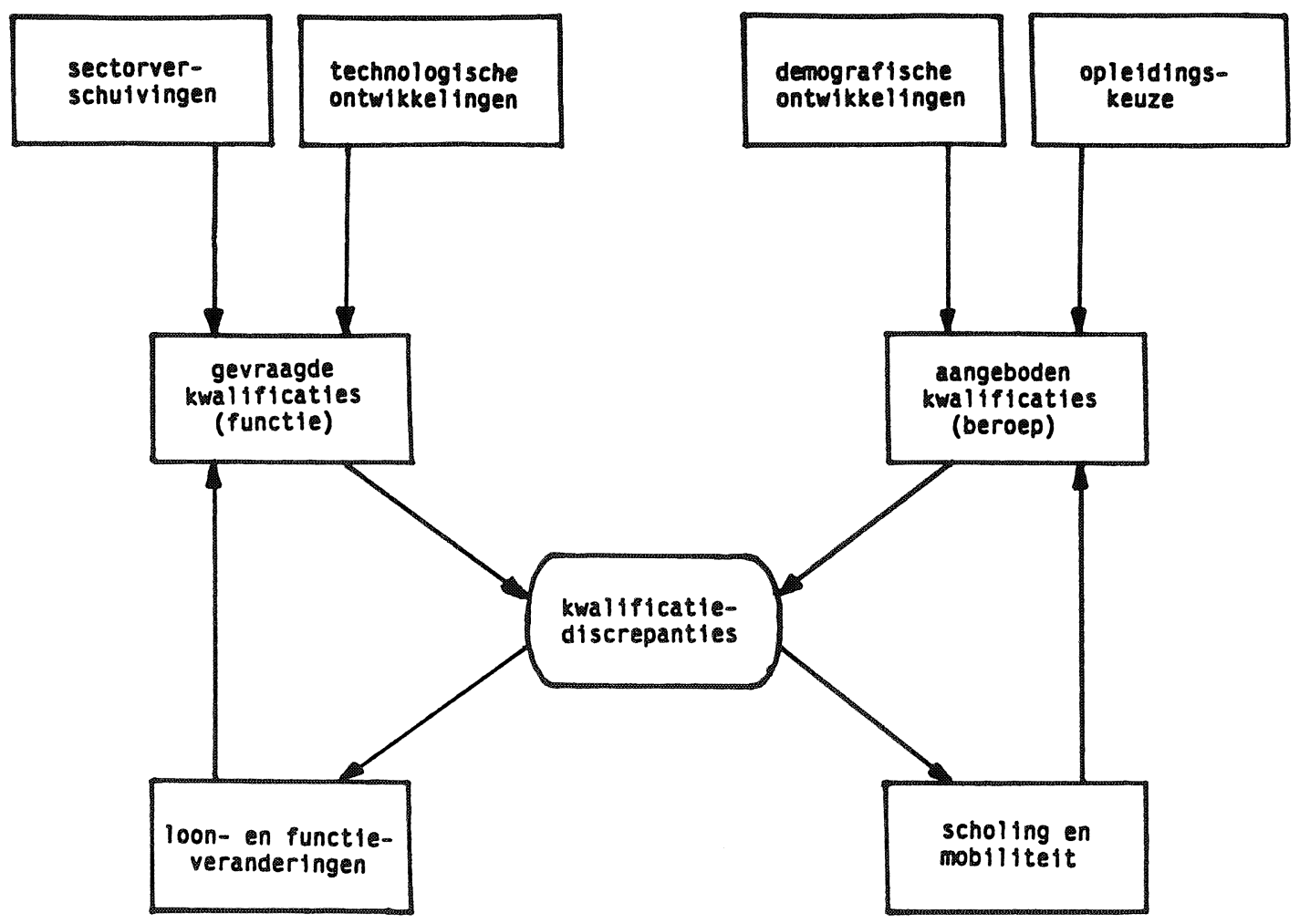


zullen beide typen beleidsinstrumenten ontwikkeld moeten worden. De situatie dat met behulp van preventief beleid alle problemen voorkomen zullen worden is onrealistisch. Daarvoor is de problematiek te complex en is verder de rol van moeilijk voorspelbare gedragsrelaties te groot. Het beleid kan immers niet gebaseerd zijn op rekenkundige exercities. Mede gezien de omvang van de problematiek, zal er altijd behoefte blijven aan curatieve maatregelen.

Een vorm van preventief beleid die binnen het onderzoeksprogramma van het ROA grote aandacht krijgt is de verbetering van informatie over de arbeidsmarktperspectieven van studierichtingen 17 . Hierbij speelt niet alleen een rol hoe prognoses over de toekomstige arbeidsmarkt opgemaakt moeten worden, maar ook in welke vorm zij moeten worden gegoten. De informatie mag immers niet even complex zijn als de arbeidsmarkt zelf, maar moet aan de andere kant toch de voor de te maken keuze relevante aspecten belichten. Een mogelijkheid om een veelheid aan informatie samen te vatten zijn zogenaamde arbeidsmarktindicatoren 18 . In de neo-klassieke gedachtengang geven de lonen alle relevante informatie over de situatie op de arbeidsmarkt. Door de verstoringen van dit neo-klassieke beeld, zoals die besproken werden in paragraaf 2.2., mag dit niet zonder meer worden aangenomen. Er moeten daarom meer indicatoren komen die te zamen een beeld geven van de arbeidsmarktsituatie. In De Grip en Heijke (1988) worden onder andere indicatoren met betrekking tot de vervangingsbehoefte, de absorptiegraad, de conjunctuurgevoeligheid, de uitwijkmogelijkheden, de concurrentiekracht en de verdringing onderscheiden. Onderzocht moet worden welke indicatoren de individuele keuze het beste ondersteunen en hoe deze indicatoren het beste gemeten kunnen worden.

\subsection{Evaluatie van beleid}

Het systematisch evalueren van beleid speelt bij een door wetenschappelijk inzicht ondersteund beleid een belangrijke rol. Om op een verantwoorde manier gebruik te maken van theoretische kennis moet tijdig worden gesignaleerd wanneer de theoretisch verwachte effecten van maatregelen niet blijken op te treden. Verder moet tijdig worden gesignaleerd welke mogelijke problemen op een bepaald moment een belangrijke rol spelen.

17. Namelijk het Project Onderwijs Arbeidsmarkt en I-See! Zie ROA (1989).

18. Zie De Grip en Heijke (1988). 
Hiertoe zullen op grond van de kennis over de oorzaken van aansluitingsproblemen statistische methodes moeten worden ontwikkeld, waarmee duidelijk het bestaan van bepaalde aansluitingsproblemen opgemerkt kan worden ('monitoring'). Een grote rol hierbij speelt de beschikbaarheid van data. Dit probleem komt in het volgende hoofdstuk aan de orde. Net zoals er indicatoren ontwikkeld moeten worden voor het ondersteunen van de studiekeuze van studenten, kunnen er ook indicatoren ontwikkeld worden die dienen ter ondersteuning van deze beleidsevaluatie. Op basis van theoretische inzichten en met continue monitoring van de arbeidsmarkt kunnen deze indicatoren aangeven wanneer, waar en welke soort aansluitingsproblemen er ontstaan.

Het constant evalueren van de effecten van het gevoerde beleid is van groot belang omdat een belangrijk deel van de maatregelen is gebouwd op veronderstelde gedragsrelaties. Deze gedragsrelaties kunnen in de 10op van de tijd veranderen. Verder kan blijken dat er nieuwe, nog onbekende problemen opduiken. Een goede feed-back kan er voor zorgen dat dit soort problemen leiden tot een vernieuwing van het theoretisch onderzoek. Op deze wijze kan de beleidsevaluatie een stimulans betekenen voor theoretisch onderzoek.

Op zijn beurt zal de beleidsevaluatie altijd geplaatst moeten worden binnen de inzichten van dit theoretisch onderzoek, omdat een ongefundeerde interpretatie van de data kan leiden tot onterechte conclusies en daarmee weer tot verkeerde beleidsmaatregelen. 


\section{VOORWAARDEN VOOR HET ONDERZOEK}

\subsection{Het belang van informatie}

De kwaliteit van onderzoek staat of valt met de kwaliteit van de voor dit onderzoek beschikbare informatie. Nadat in het vorige hoofdstuk is ingegaan op de verschillende facetten en ontwikkelingen van het onderzoek op het terrein van de aansluiting tussen het hoger onderwijs en de arbeidsmarkt zal daarom in dit hoofdstuk bekeken worden in hoeverre de bestaande informatiebronnen toereikend zijn voor de uitvoering van een onderzoek naar de aansluitingsproblematiek en welke uitbreidingen van de beschikbare informatie gewenst zijn. In de tweede paragraaf wordt aangegeven hoe inzichten uit beide bronnen van informatie en uit de theorie de beschikbare data geschikter kunnen maken voor de bestudering van de aansluitingsproblematiek.

\subsection{Behoefte aan data}

Een allereerste vereiste voor goed onderzoek is de beschikbaarheid van goede data. Dit geldt niet alleen voor empirisch onderzoek, maar ook voor onderzoek dat gericht is op het vergroten van het theoretisch inzicht. Theoretische inzichten dienen immers getoetst te worden aan de empirie. Discrepanties tussen theorie en empirie kunnen op deze wijze de theorievorming stimuleren.

De kwaliteit van de data is ook van belang indien de interesse voor de aansluitingsproblematiek verder gaat dan een zuiver theoretische interesse. Indien men door middel van beleid de aansluitingsproblemen wil verkleinen zijn betrouwbare data essentieel voor het nemen van de vereiste maatregelen. Verder kan met een voortdurende dataverzameling ('monitoring') bekeken worden of zich aansluitingsproblemen voordoen en of de genomen maatregelen daadwerkelijk het gewenste effect hebben. Indien het laatste niet het geval is kan er tijdig verandering aangebracht worden in het gevoerde beleid.

Vanwege de complexiteit van de aansluitingsproblematiek zal het niet mogelijk zijn via beleidsmaatregelen tot een fijnafstemming van de aansluiting tussen hoger het onderwijs en de arbeidsmarkt te komen. Dit betekent echter niet dat het voor het te voeren beleid niet relevant is inzicht te hebben in de aard en omvang van de problemen die zich hier voordoen. 
Bovenstaande onderstreping van het belang van goede data roept de vraag op aan welke soort data behoefte is voor het kunnen volgen in de tijd van de indicatoren betreffende de aansluiting tussen hoger onderwijs en de arbeidsmarkt en voor de bestudering van de aansluitingsproblematiek. Verder dient bekeken te worden of de bestaande data-verzameling voldoet aan de eisen die een diepgaande studie van de aansluitingsproblematiek vraagt.

De bestaande bronnen zijn veelal databestanden die niet gemaakt zijn met het oog op onderzoek naar de aansluiting tussen het onderwijs en de arbeidsmarkt. De voornaamste bronnen zijn de CBS-statistieken en sinds enkele jaren panel-enquêtes, zoals de OSA-enquête en het Sociaal Economisch Panel van het CBS.

Door hun algemene opzet leveren deze data-bestanden vaak slechts zeer globale cijfers over het onderwijs en de arbeidsmarkt. De tot nog toe meest uitgebreide informatie-bron is de Enquete BeroepsBevolking (EBB) van het CBS. Dit is de opvolger van de Arbeidskrachtentelling (AKT). De EBB is vanwege haar steekproefkarakter echter ontoereikend om gefundeerde uitspraken te kunnen doen op een laag aggregatieniveau. Verder is de termijn tussen het moment van dataverzameling en het moment waarop de gegevens beschikbaar zijn voor analyse erg lang. Op het moment bedraagt deze vertraging twee jaar. Een derde beperking van de EBB is dat zij geen informatie verschaft over enkele zaken die voor onderzoek naar de aansluitingsproblematiek van groot belang zijn19.

Het onderzoeksterrein onderwijs/arbeidsmarkt vraagt om zeer specifieke gegevens. Het doel is immers het opsporen van discrepanties en hoe hoger de aggregatiegraad des te meer discrepanties aan het oog verloren gaan. Op een hoog aggregatie-niveau kunnen vraag en aanbod immers goed met elkaar in overeenstemming lijken, terwijl op een lager aggregatie-niveau er toch vele discrepanties blijken te bestaan.

Een onderwerp als discriminatie op grond van groepskenmerken kan onmogelijk aan het licht gebracht worden als de onderzoeker zelf ook niet over meer gegevens beschikt dan het gemiddelde per groep. Hij zal dan immers dezelfde conclusie trekken als de ondernemer.

19. Deze nadelen zijn te vinden in Van Dam, De Grip en Heijke (1989). 
Het terrein onderwijs/arbeidsmarkt vraagt met name om zeer gedetailleerde informatiebronnen waarin onderscheid wordt gemaakt naar zoveel mogelijk kenmerken, die voor het onderwerp van belang zijn. Het bestaande onderzoek wordt vaak belemmerd door het niet bestaan van goed datamateriaal. Dit blijkt ondermeer uit het feit dat de beschikbaarheid van nieuwe data, vaak leidt tot een golf van nieuw onderzoek.

Bepaalde voor het onderzoek zeer belangrijke elementen zijn onnauwkeurig of ontbreken in de huidige dataverzameling. Zo is bijvoorbeeld bekend dat de cijfers van de geregistreerde werkloosheid ernstig vervuild zijn. Verder bestaat er ook geen goede registratie van vacaturegegevens.

In Van Dam, De Grip en Heijke (1988) worden de informatiebronnen over de arbeidsmarktpositie van academici geinventariseerd. De belangrijkste conclusie van deze inventarisatie is dat de weinige informatie die er al is op dit gebied, ook nog sterk verbrokkeld is, doordat de informatie is verzameld door individuele instituten. Hierdoor is er ook geen uniformiteit in de vorm en de aard van de gegevens.

In het buitenland zijn enkele voorbeelden te vinden van een systematische informatieverzameling. Van Dam, De Grip en Heijke noemen Groot-Brittanië als voorbeeld. Daar wordt aan het eind van ieder kalenderjaar onder auspiciën van de Association of Graduate Careers Advisory Services via de verschillende universiteiten een standaardvragenlijst voorgelegd aan alle afgestudeerden uit het voorbije academische studiejaar.

Bij het ROA zijn een aantal initiatieven genomen om te komen tot een verbetering van de informatievoorziening. Deze projecten zijn bedoeld voor de verwezenlijking van een monitoringsysteem en de opbouw van een databestand voor analyses en prognoses. In Van Dam, Heijke en Ramaekers (1989) wordt een pilotstudie verricht naar de mogelijkheden om de loopbanen van afgestudeerde gezondheidswetenschappers in kaart te brengen (te monitoren). Via vragenlijsten wordt zowel bij afgestudeerden als bij potentiële werkgevers informatie verzameld die relevant is voor de arbeidsmarktpositie van gezondheidswetenschappen. Het is de bedoeling dat de studie een algemeen toepasbaar instrument oplevert en dus ook bruikbaar zal zijn voor andere studierichtingen.

Een andere registratieproject is de Registratie Uitstroom en Bestemming van 
Schoolverlaters (RUBS). Dit project heeft als doel te komen tot een landelijke registratie van de uitstroom en de positie van schoolverlaters.

Deze vormen van data-verzameling zijn momenteel echter nog slechts in ontwikkeling en betreffen nog niet de volle breedte van het onderwijs en de arbeidsmarkt. Veel aandacht moet ook nog worden besteed aan onderzoek naar de meest doelmatige organisatievorm, onderzoekmethode en meetinstrumenten om dit soort data te verzamelen.

\subsection{Adequate classificaties}

Zoals reeds eerder werd opgemerkt zijn de bestaande databestanden vaak niet primair gericht op de problematiek onderwijs/arbeidsmarkt. Dit komt ook aan het licht als men bekijkt op welke wijze de gegevens in deze bestanden zijn geaggregeerd. Door aggregatie gaat altijd informatie verloren, maar de ernst van dit verlies hangt mede af van de gebruikte classificatiesystemen. De classificaties van het CBS zijn vaak minder geschikt voor een studie naar de aansluitingsproblematiek.

In het paper Clustering Occupational Classes by Educational Structure 20 is door het ROA een eerste aanzet gegeven voor het vormen van classificaties die beter toegespitst zijn op de specifieke eisen die de aansluitingsproblematiek stelt. Er kan wat dit betreft een onderscheid worden gemaakt tussen administratieve en functionele classificaties. In een administratieve classificatie worden beroepen geclusterd die op administratieve gronden overeenkomsten vertonen. Zo worden bijvoorbeeld verplegend personeel en artsen in een groep gestopt. Een functionele indeling is daarentegen gebaseerd op een objectief criterium. In het onderzoek van De Grip, Groot en Heijke (1987) is dat de onderwijsstructuur van een beroep. Dat wil zeggen dat beroepen waarin mensen werkzaam zijn met vergelijkbare onderwijsachtergrond samengenomen worden in een groep.

Het criterium op grond waarvan een groepsindeling wordt gemaakt kan op theoretische gronden worden gebaseerd. Hiermee kan gepoogd worden het verlies aan informatie door aggregatie zo klein mogelijk te houden. Hierdoor sluiten data die op grond van een functionele indeling zijn gegroepeerd beter aan op de theorie en zullen empirische studies beter mogelijk zijn.

20. De Grip, Groot en Heijke (1987). 
Van belang is echter wel dat er uniformiteit van indelingen wordt nagestreefd. Als bij iedere informatiebron gebruik wordt gemaakt van een eigen classificatie gaat een groot deel van de gebruiksmogelijkheden weer verloren. Omdat niet iedere informatieverzameling gericht is op de aansluiting onderwijs-arbeidsmarkt kan dat betekenen dat er concessies gedaan moeten worden ten opzichte van de ideale classificaties. 


\section{SAMENVATTING EN CONCLUSIES}

\subsection{Samenvatting: De relatie tussen onderzoek, gegevensverzameling en beleid}

Centraal punt in dit rapport is de relatie tussen theoretisch onderzoek, gegevensverzameling en beleid. In deze samenvatting worden deze relaties nog eens kort geschetst aan de hand van schema III (zie blz. 34).

Het signaleren van aansluitingsproblemen wordt gevoed vanuit drie poten: theorie, data en beleid. Ten eerste kan een aansluitingsprobleem nooit gesignaleerd worden zonder een theoretisch kader. Verschijnselen op zich zijn zonder betekenis. Deze betekenis krijgen ze pas binnen een theoretisch frame-work. Aan de andere kant vraagt het signaleren van aansluitingsproblemen om meer dan een theorie. De term 'problemen' geeft immers al aan dat er sprake is van een oordeel. Om problemen te kunnen constateren moeten de verschijnselen geconfronteerd worden met de doelstellingen. Deze kunnen niet vanuit de theorie aangeleverd worden, maar moeten worden vastgesteld vanuit de beleidsvoerende instantie. De rol van data bij het signaleren van aansluitingsproblemen is zonder meer duidelijk.

Beleid kan zowel preventief als curatief van aard zijn. In beide gevallen zal het beleid echter ondersteund moeten worden door de gesignaleerde problemen en door het door de theorie ontwikkelde inzicht in de werking van de aansluiting onderwijs/arbeidsmarkt. Het beleid kan worden uitgevoerd met behulp van beleidsinstrumenten. Apart genoemd is de verbetering van de informatievoorziening over onderwijs en arbeidsmarkt, omdat die in onze ogen een zeer belangrijke plaats inneemt binnen de mogelijke beleidsinstrumenten.

Door het gevoerde beleid, maar ook door diverse exogene veranderingen zal de situatie op de arbeidsmarkt veranderen. Via dataverzameling kan een monitoring van deze veranderingen plaatsvinden. De methode van monitoring moet worden ondersteund vanuit de theorie. De nieuwe gegevens kunnen vervolgens gebruikt worden voor het signaleren van (nieuwe) aansluitingsproblemen, maar dienen ook voor beleidsevaluatie. Bij beleidsevaluatie wordt er gekeken of het beleid de voorspelde effecten heeft gehad. Een discrepantie tussen de voorspelde effecten en de waargenomen effecten kan vervolgens weer dienen als stimulans voor verder theoretisch onderzoek. 
$-34-$
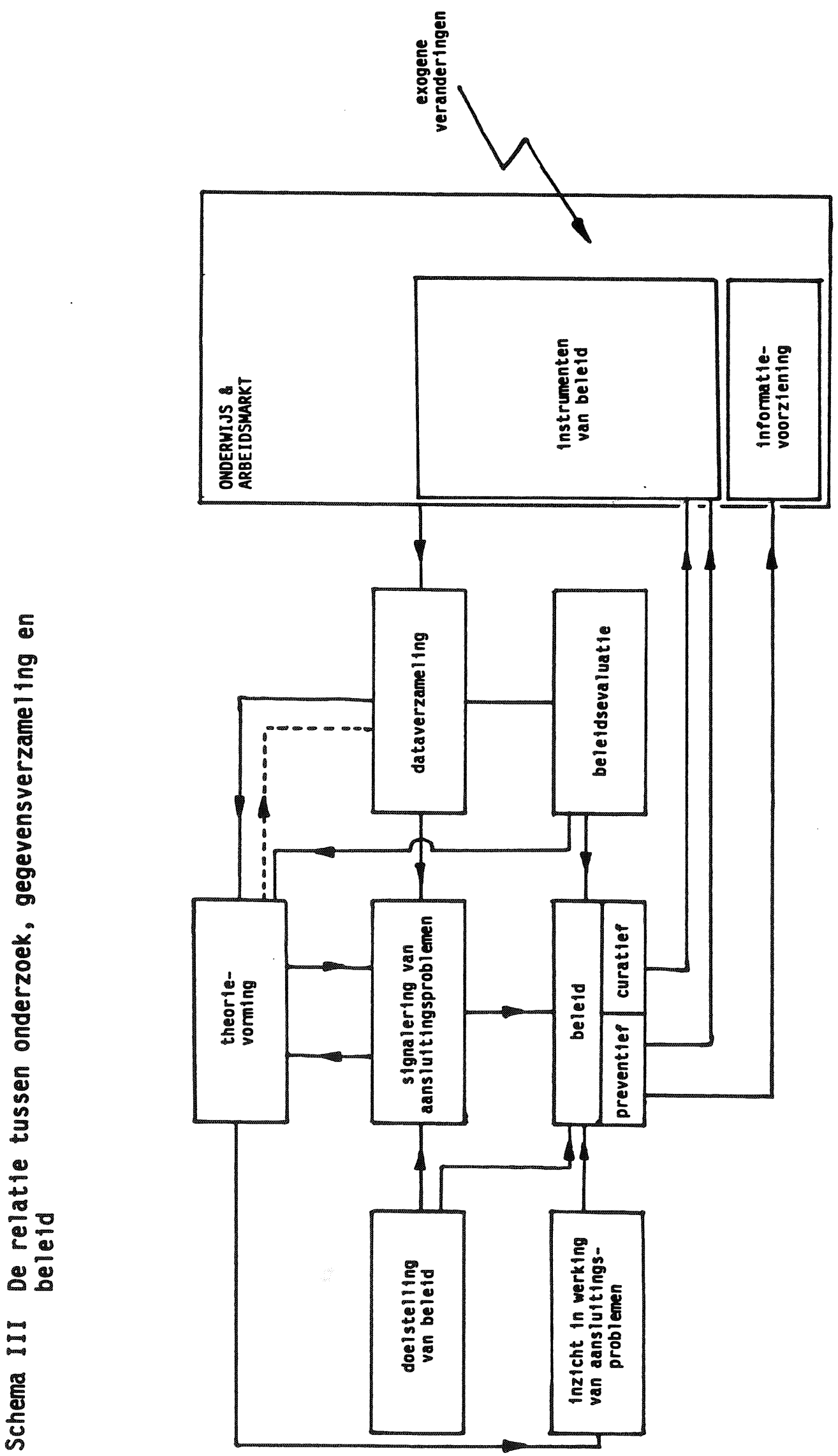


\subsection{Conclusies}

Onderzoek naar de aansluiting tussen het hoger onderwijs en de arbeidsmarkt staat voortdurend in het teken van de beleidsmogelijkheden die de situatie kunnen verbeteren. Dit wil echter niet zeggen dat fundamenteel onderzoek bij de bestudering van deze problematiek geen essentiële plaats inneemt. Beleid heeft immers altijd theoretische uitgangspunten en het is uiteraard aan te bevelen deze uitgangspunten te baseren op fundamenteel theoretisch onderzoek en niet op naijeve impliciete aannames omtrent het functioneren van de relatie onderwijs en arbeidsmarkt.

In dit rapport worden vier aspecten van de aansluitingsproblematiek genoemd. Al deze vier aspecten vragen om theoretisch onderzoek.

Het eerste aspect is de aard van de aansluitingsproblematiek. De aansluiting tussen het hoger onderwijs en de arbeidsmarkt is pas problematisch in het licht van bepaalde doelstellingen. Om beleidsinstrumenten te kunnen beoordelen moet onderzocht worden hoe de relatie tussen aansluitingsproblemen en doelstellingen ligt.

Ten tweede is voor een gefundeerd beleid van belang dat de werking van de relaties op het gebied van de aansluiting tussen het hoger onderwijs en de arbeidsmarkt worden onderzocht. Zoals reeds is vermeld zou beleid een goede theoretische onderbouwing moeten hebben en niet moeten uitgaan van impliciete ondoordachte vooronderstellingen over hoe de aansluiting werkt.

Het derde aspect is de ontwikkeling van beleidsinstrumenten. In het licht van de doelstellingen en de inzichten over de werking van de relaties op het gebied van de aansluiting tussen het hoger onderwijs en arbeidsmarkt moet bekeken worden welke beleidsinstrumenten het meest geschikt zijn om bepaalde vormen van aansluitingsproblemen tegen te gaan. Hierbij kan onderscheid gemaakt worden tussen preventieve en curatieve matregelen.

Een belangrijke vorm van preventief beleid is de verbetering van de informatie over de arbeidsmarkt. Onderzocht moet worden hoe deze informatie verkregen kan worden en in welke vorm hij het beste de beslissingen van studenten, werknemers en werkgevers kan ondersteunen.

Het laatste aspect betreft de evaluatie van het beleid. Vanwege de complexi- 
teit van de problematiek is het van groot belang continu na te gaan of het gevoerde beleid de gewenst effecten met zich mee brengt en of er nieuwe aansluitingsproblemen ontstaan. Deze doorlopende evaluatie kan er voor zorgen dat het beleid tijdig wordt aangepast indien dit nodig is. Verder kunnen de bevindingen van deze evaluaties een impuls zijn voor verder theoretisch onderzoek. Ook voor een adequate evaluatie zullen indicatoren ontwikkeld moeten worden waarmee aansluitingsproblemen snel en duidelijk gesignaleerd kunnen worden.

Naast deze vier aspecten van theoretisch onderzoek is het verzamelen van data van groot belang. Met behulp van een monitoring-systeem dient doorlopend informatie verzameld te worden over de aansluiting tussen het hoger onderwijs en de arbeidsmarkt.

In de eerste plaats zijn zulke data van groot belang voor het uitvoeren van theoretisch onderzoek naar het functioneren van de relatie tussen het onderwijs en de arbeidsmarkt. Ten tweede is er ter ondersteuning van het beleid behoefte aan informatie over de aard van de aansluitingsproblemen. Ten derde zal er voor een verbetering van de informatievoorziening aan de betrokken partijen ook voldoende informatie beschikbaar moeten zijn. Tenslotte is een goed monitoring-systeem onmisbaar voor het uitvoeren van een goede evaluatie van het gevoerde beleid. Om te komen tot een goed werkend monitoring-systeem zal onderzoek moeten worden gedaan naar de wijze waarop dit het best kan geschieden. 


\section{LITERATUUR}

Albinski, $M_{0}$, Studentenstop: verslag van een simulatieproject. In $H_{0} A_{\text {. }}$ Becker (red.), Simulatie in de sociale wetenschappen, Alphen aan den Rijn, 1976.

Dam, J.W. van, A. de Grip en J.A.M. Heijke, Op zoek naar informatiebronnen over de arbeidsmarktpositie van academici, ROA-W-1988/3, Maastricht

Dam, J.W. van, J.A.M. Heijke en G.W.M. Ramaekers, Ontwerp van een arbeidsmarktscanner voor academici, ROA-R-1989/3, Maastricht.

Diederen, J., Meer of minder ongelijk, Nijmegen, 1989.

Doeringer. P.B., en M.J. Piore, Internal Labor Markets and Manpower Analyses, Lexington, 1971.

Freeman, R.B., The Overeducated American. New York, 1976.

Freeman, R.B., Employment Opportunities in the Doctorate Manpower Market, Industrial and Labor Relations Review, 1980, pp. 185-197.

Grip, A. de, Onderwijs en arbeidsmarkt: scholingsdiscrepanties, dissertatie, Amsterdam, 1987.

Grip, A. de, L.F.M. Groot en J.A.M. Heijke, Clustering Occupational Classes by Educational Structure. ROA-W-1987/2E, Maastricht.

Grip, A. de, en J.A.M. Heijke, Arbeidsmarktindicatoren: een inventarisatie. ROA-W-1988/1, Maastricht.

Hartog, J., Tussen vraag en aanbod, Leiden-Antwerpen, 1980.

Hartog, J., Earnings Functions: beyond Human Capital, Applied Economics, 1986, pp. 1291-1309.

Hoof, J.J., van, J. Dronkers, Onderwijs en arbeidsmarkt; een verkenning van de relatie tussen onderwijs, arbeidsmarkt en arbeidssysteem. Deventer, 1980.

Kodde, D.A., Microeconomic Analys is of Demand for Education, dissertatie Rotterdam, 1985.

Mourik, A. van, Th. J. de Poel en J.J. Siegers, Ontwikkelingen in de beroepssegregatie tussen mannen en vrouwen in de jaren zeventig. In: Economische Statistische Berichten, 1983, blz. 597-601.

Parsons, D.0., The Employment Relationship: Job Attachment, Work Effort and the Nature of Contracts. In: Handbook of Labor Economics, vol. 2, 1986, pp. 789-848.

Rosen, S., Implicit Contracts: a Survey, Journal of Economic Literature, 1985, pp. 1144-1175.

Psacharopoulos, G., The Manpower Requirements Approach. In: G. Psacharopoulos, Economics of Education, Oxford, 1987, pp. 331-33575.

Soest, A. van, I. Woittiez, A. Kapteyn, Labour Supply, Income Taxes and Hours Restrictions in the Netherlands. CentER Discussion paper 8903, 1989. 
Spence, M., Job Market Signalling, Quarterly Journal of Economics, 1973, b1z. 355-374.

Stiglitz, Theories of Wage Rigidities. In: J.L. Butkiewicz, K.J. Koford en J.B. Miller (red.), Keynes' Economic Legacy: Contemporary Economic Theories, (1986).

Thurow, L.C., Generating Inequality, New York, 1975.

Thurow, L.C., A Job Competition Model. In: M.J. Piore (red.), Unemployment and Inflation, 1979.

Tinbergen, J., Income Distribution, Analys is and Policies. Amsterdam, 1975.

Voorden, W. van, Institutionalisering en arbeidsmarktbeleid, Alphen aan den Rijn, 1975.

Zarkin, G.A., Occupational Choice: An Application to the Market for Public School Teachers. Quarterly Journal of Economics, 100 (1983), pp. 409-446. 